\title{
NOSTE-OHJELMA ON KOULUTUSPOLIITTINEN AVAUS
}

E duskunnan ja opetusministeriön väännön tuloksena valtion budjettiin on tälle vuodelle varattu 12 miljoonaa euroa vailla toisen asteen tutkintoa eli lukion tai ammattikoulun tutkintoa olevien 30-54-vuotiaiden koulutustason kohottamisohjelman aloittamista varten. Vailla perusasteen tutkintoa olevat voivat jo 25 -vuotiaina hakeutua ohjelmaan. Alkurahoitus mahdollistaa "Noste"- ohjelman käynnistämisen ja arviolta 3000 henkilön kouluttamisen. Hallitusohjelmassa sitoudutaan koulutettavien määrän nostamiseen tulevina vuosina vähintään 10000 :een vuodessa. Ohjelman on tarkoitus kestää viisi vuotta eli vuoden 2007 loppuun.

Aloitteen aikuisten koulutustason kohottamisohjelmasta teki Parlamentaarinen aikuiskoulutustyöryhmä. Ohjelman taustalla ovat kansainvälisissä selvityksissä ja arvioinneissa varmistuneet suuret sosiaalisen aseman, koulutustason ja iän mukaiset erot aikuiskoulutukseen osallistumisessa Suomessa. Kun jo lähitulevaisuus merkitsee ikääntyvän väestön ja mahdollisesti samanaikaisesti työttömyyden ja työvoimapulan yhteiskuntaa asetti valtioneuvosto tammikuun lopulla annetussa asetuksessa ohjelman tavoitteiksi:

"parantaa enintään perusasteen tutkinnon suorittaneiden aikuisten työelämässä pysymistä ja urakehitystä, lieventää suurten ikäluokkien eläkkeelle siirtymisen aiheuttamaa työvoimavajausta ja vaikuttaa työllisyysasteeseen" ( $V N$ 41/2003).

Koulutuspolitiikan seuraajalle Noste-ohjelma merkitsee uutta koulutuspoliittista avausta. Kun esimerkiksi tuoreessa koulutuspoliittisessa pamfletissa "Kohti asiantuntijayhteiskunnan koulutuspolitiikkaa" (Poropudas \& Volanen 2003) kysytään, merkitseekö aikuiskoulutus vain kasautuvaa hyvää, on Noste-ohjelmassa mahdollisuus muuttaa tätä yhteiskunnallista asemaa noudattavaa koulutukseen osallistumisen kasautumisen mallia. Mitkä ovat ne tekijät, jotka tekevät tämän mahdolliseksi?

Ensimmäinen tekijä on erityisen ohjelman ja siihen liittyvän taloudellisen ja ohjauksellisen tuen olemassaolo. Kansainväliset kokemukset kertovat, että vähän koulutusta saaneiden liikkeelle lähtö edellyttää julkisen vallan tai työnantajan erityistä tukea (Tuijnman \& Hellström 2001). Lähin esimerkki on Ruotsin tiedontason kohottamisohjelma (kunskapslyftet), joka päättyi viime vuoden lopussa ja jonka kokemuksista on siten mahdollista oppia. On tosin muistettava, että niin ohjelmat kuin koulutusorganisaatiotkin ovat Ruot-

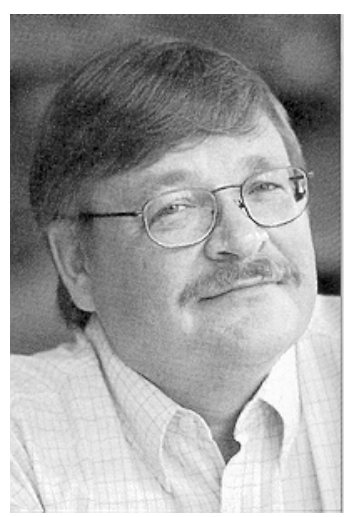

Ari Antikainen sissa ja Suomessa erilaiset.

Toinen tekijä on koulutuksen organisaatio. Koulutusta ollaan organisoimassa verkostomuotoisiksi yhteistyöorganisaatioiksi. Siis monien toimijoiden on tarkoitus yhdistää voimansa lähinnä alueelliselta pohjalta. Näen mallin takana Manuel Castellsin ajattelun soveltamisen.

Kolmas tekijä on opetuksen järjestelyt ja menetelmät. Työssä oppimisen ja oppisopimuskoulutuksen kaltaiset menetelmät ovat keskeisessä asemassa. Kysymys ei siis ole aikuisten saattamisesta "koulun penkille" tai "pulpettisulkeiseen".

Neljäs tekijä on opintojen ohjaus. Sille on varattu oma osansa budjetista ja siihen on tarkoitus kiinnittää huomiota. Asiantuntijoiden lisäksi ohjauksen muitakin menetelmiä, kuten vertaisohjausta, on tarkoitus käyttää ja kehittää. Onnismaan (2003) sanoin: "Ohjaus ei ole rahankulua, vaan yksilön ja yhteiskunnan kannalta tuottavaa toimintaa."

Viides tekijä on koulutuspoliittisten toimijoiden piirissä tapahtuva muutos. Ammatilliselle aikuiskoulutukselle Noste on näytön paikka. On odotettavissa, että ammatilliset aikuiskoulutuskeskukset vastaavat haasteeseen. Lisäksi jo nyt on tiedossa, että SAK on lähdössä vakavasti mukaan. Toki SAK on aiemminkin ollut kiinnostunut jäsentensä kouluttautumisesta, mutta nyt merkit viittaavat siihen, että se on tulossa todelliseksi toimijaksi jäsentensä osaamisen ja koulu- 
tuksen kysymyksissä. Poliittisen tukensa Noste-ohjelma on saanut ennen muuta tulopoliittisten neuvottelujen osapuolilta, ja työnantajat ovat tietenkin tässä avainryhmä.

Nosteen kohderyhmä on mm. ammattirakenteeltaan varsin monipuolinen ja noin puolella heistä on jo suunnitelmia koulutukseen osallistumisesta (Kokkila 2003). He ovat pitäneet viime vuosikymmeninä kansantalouden pyörät pyörimässä ja maksaneet veronsa, joilla mekin ja lapsemme olemme osaltamme kouluttautuneet. Odotan kiinnostuneena heidän vastaustaan valtiovallan ja työmarkkinaosapuolten esittämään haastavaan tarjoukseen.

Toivon lyhyesti esittämieni näkökohtien kertovan Nosteen kiinnostuksen ja haasteen myös koulutustutkimukselle.

\section{Ari Antikainen}

Noste-ohjelman ohjausryhmän jäsen

\section{LÄHTEITÄ}

Kokkila, H. (2003). Elinikäiseksi oppijaksi aikuisiällä? Vailla toisen asteen tutkintoa olevien 30-54-vuotiaiden osallistuminen aikuiskoulutukseen ja käsitykset koulutuksen tarpeista. Pro Gradu -tutkielma, Joensuun yliopisto.

Onnismaa, J. (2003) Opintojen ohjaus jäänyt puutteelliseksi. Helsingin Sanomat, mielipide 15.4.2003.

Poropudas, O. \& Volanen, V.-M. (2003) Kohti asiantuntijayhteiskunnan koulutuspolitiikkaa. Helsinki: Omakirja.

Tuijnman, A. \& Hellström, Z. (eds.) (2003) Curious Minds: Nordic Adult Education Compared. Copenhagen: Nordic Council.

\section{NOSTE-KOULUTUKSEN ENSIMMÄINEN HAKUKIERROS TAKANA}

Lääninhallitukset ovat saaneet koulutuksen järjestäjiltä 140 hakemusta, joista 90 perustuu tavoiteltuun oppilaitosten ja koulutuksen järjestöjien alueelliseen yhteistyöhön. Hakemuksista 22 oli valtakunnallisia. Opetusministeriössä työskentelevän Noste-koulutuksen projektipäällikön Marja Pakasteen mukaan kynnyskysymys koulutusohjelman onnistumisessa on se, tavoittaako tieto oikeat kohderyhmät ja hakevatko koulutusta juuri ne työelämässä olevat ihmiset, joille se on tarkoitettu. 